\title{
NodC-based evaluation of the occurrence of bacteria in nodules of Pisum sativum isolated on YEM agar
}

\section{NodC-basierte Bewertung des Auftretens von Bakterien in Wurzelknöllchen von Pisum sativum, isoliert auf YEM-Agar}

\author{
Anna Lenart-Boroń ${ }^{1 *}$, Tadeusz Zając², Piotr Mateusz Boroń ${ }^{3}$, Agnieszka Klimek-Kopyra ${ }^{2}$
}

\footnotetext{
${ }^{1}$ Department of Microbiology, University of Agriculture in Cracow, Al. Mickiewicza 24/28, 30-059 Cracow, Poland

${ }^{2}$ Department of Crop Production, University of Agriculture in Cracow, Al. Mickiewicza 21, 31-120 Cracow, Poland

${ }^{3}$ Department of Forest Pathology, Mycology and Tree Physiology; University of Agriculture in Cracow, Al. 29 Listopada 46, 31-425 Cracow,

Poland

* Corresponding author: anna.lenart-boron@urk.edu.pl
}

Received: 3 October 2018, received in revised form: 10 December 2018, accepted: 10 December 2018

\begin{abstract}
Summary
The bacterial nodulation $(n o d)$ genes are essential in the formation process of root nodules. This study was aimed to verify the occurrence of nodule-associated bacteria in two pea varieties ("Tarchalska" and "Klif") inoculated with Rhizobium inoculants - Nitragine ${ }^{\mathrm{TM}}$ and a noncommercial one produced by the Polish Institute of Soil Science and Plant Cultivation (IUNG). The number of colonies isolated on yeast extract mannitol (YEM) agar from the nodules of "Klif" inoculated with IUNG inoculants was significantly higher than the number of colonies isolated from other variants. Species identification was based on sequencing of $16 S$ rDNA, which revealed that despite careful sterilization of nodules, sequences of other bacterial species were detected. Among them, one sequence belonged to Rhizobium leguminosarum (isolated from IUNG inoculant). To assess the presence of nodulation-capable Rhizobium, amplification of the nodC gene was performed, which revealed that of 29 samples, 19 were positive. The remaining isolates, including reference strain and bacteria isolated from Nitragine ${ }^{\mathrm{TM}}$, lacked this gene. The results show that pea nodules harbor a very diverse community of bacteria. The lack of nodC gene in some strains isolated from plants inoculated with Nitragine ${ }^{\mathrm{Tm}}$ and with IUNG inoculant proves that even if $R$. leguminosarum are abundant, they may not be efficient in nodulation.
\end{abstract}

Keywords: Rhizobium leguminosarum bv. viceae, Pisum sativum L., inoculant, nod genes, $16 \mathrm{~S}$ rDNA sequencing

\section{Zusammenfassung}

Die bakteriellen Nodulationsgene (nod) sind für den Bildungsprozess der Wurzelknöllchen wesentlich. Diese Studie zielte darauf ab, das Vorkommen von knöllchenassoziierten Bakterien in zwei Erbsensorten zu überprüfen („Tarchalska“ und „Klif“), die mit einem Rhizobium-Inokulat, Nitragine ${ }^{\tau M}$, oder einem nicht kommerziellen Produkt, hergestellt vom Polnischen Institut für Bodenkunde und Pflanzenanbau (IUNG), beimpft wurden. Die Anzahl der auf YEM-Agar isolierten Kolonien, die aus mit IUNG geimpften Knöllchen von "Klif" isoliert wurden, war signifikant höher als die Anzahl der aus anderen Varianten isolierten Kolonien. Die Identifizierung der Spezies beruhte auf der Sequenzierung von 16S-rDNA, die ergab, dass trotz sorgfältiger Sterilisation der Knöllchen Sequenzen von anderen Bakterienarten nachgewiesen wurden. Unter ihnen gehörte nur eine Sequenz zu R. leguminosarum (Bakterien, die aus dem IUNG-Impfstoff isoliert wurden). Um das Vorhandensein von nodulationsfähigem Rhizobium zu bestimmen, wurde eine Amplifikation des nodC-Gens durchgeführt, die ergab, dass von 29 Proben nur 19 positiv waren. Bei den verbleibenden Isolaten, einschließlich des Referenzstamms und der aus Nitragine ${ }^{\mathrm{TM}}$ isolierten Bakterien, fehlte dieses Produkt. Die Studie zeigen, dass die Erbsenknöllchen eine sehr unterschiedliche Bakteriengemeinschaft beherbergen. Das Fehlen des nodC-Gens in einigen Stämmen, die sowohl aus mit Nitragine ${ }^{\mathrm{TM}}$ als auch mit IUNG beimpften Pflanzen isoliert wurden, beweist, dass, auch wenn $R$. leguminosarum reichlich vorhanden ist, diese bei der Pflanzennodulation nicht wirksam sein können.

Schlagworte: Rhizobium leguminosarum bv. viceae, Pisum sativum L., Beimpfung, nod Gene, 16S-rDNA-Sequenzierung 


\section{Introduction}

Among legumes, pea (Pisum sativum L.) is the second most important grain legume crop in the world, which is widely used as green vegetable, seed, pasture, silage, hay, and green manure (Cristou, 1997; Wadhwa et al., 2011). The global area of green peas cultivation is 2.3 million ha (FAO, 2013). The general awareness of increasing soil and water pollution caused by the use of chemical fertilizers has also increased the importance of legumes (Tas et al., 1995). However, the pea yield can vary strongly depending on various factors, resulting in lower yields of pea plants in Eastern Europe than in Western part of the continent (Doré et al., 1998). According to Klimek-Kopyra et al. (2017), the seed yield of pea can vary in different years of cultivation, which might be associated with agro-climatic conditions, and also can be affected by the genotype variety and - to some extent-by the applied inoculant. At present, rhizobial inoculation of pea seeds is one of agronomic solutions for sustainable agriculture development. Commercial bacterial inoculants are produced in many countries. Their quality depends on both the abundance of Rhizobium spp. bacteria and their effectiveness in fixing nitrogen with the target host (Amarger et al., 1997). Symbiotic effectiveness is one of the most important factors when selecting an inoculant strain (Stephens and Rask, 2000). On the other hand, Rhizobium populations present in the soil will affect the outcome of the inoculation (Thies et al., 1991), because indigenous inefficient strains are often better adapted to the prevailing soil and climatic conditions (Wadhwa et al., 2011). Therefore, searching for best strains and evaluation of the existing inoculants is crucial both for bacterial improvement and for pea cultivation. The process of interaction between leguminous plants and Rhizobium bacteria starts when root hairs - the target for rhizobia - start to deform and curl to form nitrogen-fixing nodules. The bacterial nodulation (nod) genes are essential for interactions with root hairs. The common group of nod genes (nodABC), which are located on a Sym plasmid, is required in all phases of root hair interaction (Debellé et al., 1986). Gloudemans et al. (1989) demonstrated that the $\operatorname{nod} C$ gene is required and essential for the induction and enhancement of expression of genes essential in the nodule formation process.

Another important aspect in terms of legume root nodules is the fact that they are hosts to several eubacterial genera other than Rhizobium, the number of which can reach even $10^{4}$ colony forming units (CFUs) of viable bacteria per gram of fresh nodule tissue. The non-rhizobial occupants of root nodules of leguminous plants may include the representatives of Bacillus, Streptomyces, Herbaspirillum, Arbuscular Mycorrhizal Fungi, Agrobacterium, and many others (Selvakumar et al. 2013). Some of these bacteria, such as Pantoea agglomerans, Enterobacter kobei, Enterobacter cloacae, Leclercia adecarboxylata, Escherichia vulneris, or Pseudomonas spp. were implicated in the nodulation process (Selvakumar et al., 2013). For a number of reasons, the use of 16S rRNA gene sequencing has been the most common method to study bacterial phylogeny and taxonomy. These reasons include the presence of the 16S rRNA gene in almost all bacteria, the fact that its function has not changed over time and its size (i.e. 1,500 bp), which is large enough for bioinformatics purposes (Patel, 2001). Having the above factors in mind, this study was aimed to assess the effect of pea plants' inoculation with two preparations containing symbiotic $\mathrm{N}_{2}$-fixing bacteria (Rhizobium spp.) - a commercial product (Nitragine') and a noncommercial one produced by the Polish Institute of Soil Science and Plant Cultivation (IUNG) - in terms of the abundance and identification of nodule-associated bacteria. Particular emphasis was on the verification of the presence and molecular diversity of the $N o d C$ gene, which is essential for the effective process of nodule formation in leguminous plants.

\section{Material and methods}

\subsection{Collection site and pea plants}

Bacterial strains were isolated from nodules of two varieties of field pea (Pisum sativum L.) — "Tarchalska" and "Klif"-cultivated in the experimental field of Bayer" company located in Modzurów, Silesia, Poland (N50 $9^{\prime} 24^{\prime \prime}$ E1 $\left.8^{\circ} 7^{\prime} 55^{\prime \prime}\right)$. A randomized system was adopted in the conducted field experiment, and it consisted of four replicates; each plot had a size of $8.4 \mathrm{~m}^{2}$. The experimental field soil was an Umbrisol, a slightly degraded chernozem, formed from loess, classified as good wheat complex and the second bonitation class; therefore, the soil conditions were sufficient for the pea needs. The topsoil had a neutral $\mathrm{pH}$ $\left(\mathrm{pH}\right.$ in $\left.1 \mathrm{~mol} / \mathrm{dm}^{3} \mathrm{KCl}: 6.28\right)$ and a high nutrient content: $191 \mathrm{ppm} \mathrm{P}_{2} \mathrm{O}_{5}, 217$ ppm $\mathrm{K}_{2} \mathrm{O}$, and $101 \mathrm{ppm} \mathrm{Mg}$. The following pre-sowing doses were applied: $48 \mathrm{~kg} \mathrm{ha}^{-1}$ of phosphorus $\left(\mathrm{P}_{2} \mathrm{O}_{5}\right)$ and $72 \mathrm{~kg} \mathrm{ha}^{-1}$ potassium $\left(\mathrm{K}_{2} \mathrm{O}\right)$. Ammonium nitrate was applied as a "starting dose" with $20 \mathrm{~kg} \mathrm{Nha}^{-1}$. Both varieties were inoculated before sowing 
with either of the two inoculants containing Rhizobium leguminosarum bv. viceae: Nitragine ${ }^{m}$ produced by the BIOFOOD company (Poland) and noncommercial gel inoculant produced by the Polish IUNG. Non-inoculated plants were used as control. The plant seeds were sown in the first week of April 2011 and in the fourth week of March 2012. One hundred and twenty germinable seeds of "Tarchalska" and of 100 germinable seeds of "Klif" variety were sown per square meter at a row distance of $15 \mathrm{~cm}$ and sowing depth of $6 \mathrm{~cm}$. Four types of nodules (large red, large cream, small red, and small cream) were selected for the study and were collected in July 2011 and 2012.

\subsection{Bacterial strains}

From each plant sampled, six pea nodules of each type (large red, large cream, small red, and small cream) were randomly excised. In total, 24 samples were used for further analyzes in each year. The collected nodules were washed with sterile water and surface sterilized using $1 \% \mathrm{NaOCl}$ for $2 \mathrm{~min}$ and then with $70 \%$ ethanol for $1 \mathrm{~min}$ and washed with sterile water for four times. After sterilization, each nodule (one nodule per each type in six replicates) was crushed with a sterile glass rod in $1 \mathrm{~cm}^{3}$ of sterile $0.85 \% \mathrm{NaCl}$ solution and shaked for $15 \mathrm{~min}$ in a Petri dish. Afterwards, the bacteria were isolated on yeast extract mannitol (YEM) agar plates. The isolates were grown at $28^{\circ} \mathrm{C}$ for 5 days and purified by repeated streaking on YEM (Vincent, 1970). Following incubation, the numbers of Rhizobium-like bacteria CFUs per one nodule of each type and each plant-inoculant combination were determined.

Moreover, bacterial isolates were derived from the two Rhizobium-based inoculants used in this study by streaking serial dilutions onto YEM agar plates. A reference strain of $R$. leguminosarum bv. viceae (DSM 30143) was also used in this study.

\subsection{Isolation of genomic DNA}

The bacterial isolates were cultured on tryptone yeast agar plates at $28^{\circ} \mathrm{C}$ and genomic DNA was extracted by following the protocol of Genomic Mini kit for genomic bacterial DNA isolation (A\&A Biotechnology, Poland).

\subsection{Amplification and sequencing of 16S rRNA gene}

The species identification of bacterial isolates was based on the sequencing of the $16 \mathrm{~S}$ rRNA gene. The partial fragment of $16 \mathrm{~S}$ rRNA gene was amplified using the primers
fD1 (5'-AGAGTTTGATCCTGGCTCAG-3') and rP2 (5'-AGAGTTTGATCCTGGCTCAG-3') (Weisburg et al., 1991). Polymerase chain reaction (PCR) solution contained $50 \mathrm{ng}$ of DNA template, $12.5 \mathrm{pM}$ of each primer, $2.5 \mathrm{mM}$ of dNTP, 1X PCR buffer, and 2.5 U Taq DNA polymerase in a total volume of $25 \mu \mathrm{l}$. The following temperature profile was used for DNA amplification: initial denaturation at $94^{\circ} \mathrm{C}$ for 5 min followed by 30 cycles of denaturation at $94^{\circ} \mathrm{C}$ for $30 \mathrm{~s}$, annealing at $62.5^{\circ} \mathrm{C}$ for $30 \mathrm{~s}$, and elongation at $72^{\circ} \mathrm{C}$ for $1 \mathrm{~min} ; 15$ cycles of denaturation at $94^{\circ} \mathrm{C}$, annealing at $48^{\circ} \mathrm{C}$, and elongation at $72^{\circ} \mathrm{C}$ for $1 \mathrm{~min}$; and final elongation at $72^{\circ} \mathrm{C}$ for $10 \mathrm{~min}$. PCR amplifications were performed using Veriti 96-Well Thermal Cycler (Applied Biosystems, USA). The PCR products were visualized by $1 \times \mathrm{TBE}$ electrophoresis in ethidium-bromide-stained, $1 \%$ agarose gel and purified using the Gel Out purification kit (A\&A Biotechnology, Poland) before sequencing. Sequencing reactions were performed on 24 samples of 165 rRNA amplicons-one sample per each of the combination. The obtained nucleotide sequences were queried against the NCBI GenBank database using BLAST search to determine the most closely related bacterial species.

\subsection{Amplification and sequencing of nodC gene}

Five primer pairs were tested for amplification of approximately 930 bp of the 1,300 bp nodC gene: forward primers used were nodCF, nodCFu, nodCF2, nodCF4, or nod$\mathrm{CFn}$, and reverse primer used were nodCI (Laguerre et al, 2001) (Table 1).

PCR solution contained 50 ng of DNA template, $12.5 \mathrm{pM}$ of each primer, $2.5 \mathrm{mM}$ of dNTP, 1X PCR buffer, and $2.5 \mathrm{U}$ Taq DNA polymerase in a total volume of $25 \mu \mathrm{l}$. The following temperature profile was used for DNA amplification: initial denaturation at $94^{\circ} \mathrm{C}$ for $5 \mathrm{~min}$ followed by 30 cycles of denaturation at $94^{\circ} \mathrm{C}$ for $30 \mathrm{~s}$, annealing at $62.5^{\circ} \mathrm{C}$ for $30 \mathrm{~s}$, and elongation at $72^{\circ} \mathrm{C}$ for $1 \mathrm{~min} ; 15$ cycles of denaturation at $94^{\circ} \mathrm{C}$, annealing at $48^{\circ} \mathrm{C}$, and elongation at $72^{\circ} \mathrm{C}$ for $1 \mathrm{~min}$; and final elongation at $72^{\circ} \mathrm{C}$ for $10 \mathrm{~min}$. PCR amplifications were performed using Veriti 96-Well Thermal Cycler (Applied Biosystems, USA). The PCR products were visualized by $1 \times \mathrm{TBE}$ electrophoresis in ethidium-bromidestained, $1 \%$ agarose gel and purified using the Gel Out purification kit (A\&A Biotechnology, Poland) before sequencing. The part of nodC gene of the selected isolates was sequenced and queried against NCBI GenBank database using BLAST search to confirm their species affiliation. 
Table 1. Oligonucleotides used for nodC amplification

Tabelle 1. Für die nodC-Amplifikation verwendete Oligonukleotide

\begin{tabular}{|c|c|}
\hline Primer & $5 '-3^{\prime}$ nucleotide sequence \\
\hline nodCF & AYGTHGTYGAYGACGGTTC \\
\hline nodCFu & AYGTHGTYGAYGACGGITC \\
\hline nodCF2 & AYGTHGTYGAYGACGGCTC \\
\hline nodCF4 & AYGTHGTYGAYGACGGATC \\
\hline nodCFn & AGGTGGTYGAYGACGGTTC \\
\hline nodCI & CGYGACAGCCANTCKCTATTG \\
\hline
\end{tabular}

\subsection{PCR-RFLP of nodC gene}

The PCR amplified, 930-bp long, nodC products were subjected to the restriction fragment length polymorphism (RFLP) analysis by digesting with five restriction endonucleases AluI, BamHI, BsuRI, EcoRI, and MspI following the manufacturer's instructions (Thermo Fisher Scientific-Fermentas, Canada). This procedure was aimed to determine the molecular diversity of rhizobial strains isolated from the analyzed pea plants. Each digestion reaction was conducted individually with one restriction enzyme at a time. After digestion, resulting fragments were visualized by $1 \times \mathrm{TBE}$ electrophoresis in ethidium-bromide-stained, $1 \%$ agarose gel. The GeneRuler ${ }^{\text {r" }} 1 \mathrm{~kb}$ DNA Ladder (Thermo Scientific) DNA size marker was used to determine the size of the bands obtained as a result of the restriction digestion. Similarly, as in the case of the restriction reactions, the results of restriction reactions were assessed in the form of one electrophoresis per one enzyme. Therefore, five different electrophoreses were prepared to analyze the RFLP results.

\subsection{Statistical analysis}

Comparison of means and least significant difference (LSD) for the CFUs of bacteria colonizing pea nodules was performed using STATISTICA v. 10 software (StatSoft Inc., Tulsa, USA).

\section{Results}

\subsection{Bacterial isolation}

The numbers of CFUs per one nodule varied significantly (Table 2). The isolates formed colonies that were visible after 5-7 days. All isolates produced colorless to whitish convex colonies with abundant extracellular gum on the surface. Of all examined variants, the highest number of colonies of nodule-colonizing bacteria was observed for the large red nodules of the IUNG-inoculated "Klif" variety of pea (310 CFU/nodule). In general, this variant showed the highest mean number of bacterial colonies per nodule (175.9 CFU/nodule). On the other hand, the smallest number of CFUs per nodule (CFU/ nodule) was observed for the uninoculated "Tarchalska" pea plants. The smallest mean number per nodule was observed for the combination of "Tarchalska" plants inoculated with Nitragine" (46.0 CFU/nodule). When considering the differences in the numbers of CFUs per nodules, the highest mean abundance was observed for the large red nodules (132.7 CFU/nodule), as it was nearly twice higher than that in the case of small red and nearly three times higher than in large cream nodules, where the mean number of CFUs per nodule was the smallest (53.2 CFU/nodule).

Table 2. The mean numbers of colony forming units (CFUs) of bacteria colonizing pea nodules per one nodule depending on variants (pea varieties and inoculants).

Tabelle 2. Die Durchschnittswerte koloniebildender Einheiten (KBE) von Bakterien, die Erbsenknollen besiedeln, pro Knöllchen in Abhängigkeit der Varianten (Erbsensorten und Inokulen).

\begin{tabular}{|c|c|c|c|c|c|}
\hline \multirow{2}{*}{ Variant } & \multicolumn{4}{|c|}{ Nodules } & \multirow[b]{2}{*}{ Mean } \\
\hline & Large cream & Small cream & Large red & Small red & \\
\hline Klif (uninoculated) & 20.5 & 87.0 & 128.5 & 52.0 & $72.0^{b}$ \\
\hline Tarchalska (uninoculated) & 6.0 & 110.0 & 157.5 & 36.0 & $77.4^{b}$ \\
\hline Klif + IUNG & 84.0 & 97.5 & 310.0 & 212.0 & $175.9^{9}$ \\
\hline Tarchalska + IUNG & 110.0 & 45.0 & 101.0 & 49.0 & $76.3^{b}$ \\
\hline Klif + Nitragine $\mathrm{T}^{\mathrm{TM}}$ & 54.0 & 79.5 & 67.0 & 39.0 & $59.9^{b}$ \\
\hline Tarchalska + Nitragine ${ }^{\mathrm{TM}}$ & 45.0 & 54.0 & 32.0 & 53.0 & $46.0^{b}$ \\
\hline Mean & $53.2^{\mathrm{b}}$ & $78.8^{\mathrm{ab}}$ & $132.7^{\mathrm{a}}$ & $73.5^{\mathrm{ab}}$ & \\
\hline
\end{tabular}

Pairs of treatments that are not significantly different according to the LSD test $(\mathrm{p}<0.05)$ share the same letter. 
Considering the plant cultivar-inoculant combination, the LSD test showed that the number of bacterial CFUs isolated from nodules of "Klif" variety combined with IUNG inoculant was significantly higher than the number of colonies isolated from other variants $(\mathrm{p}<0.05)$ (Table 2).

\subsection{Molecular characterization of isolates}

In order to verify the identity of isolated strains, the $16 \mathrm{~S}$ rRNA gene was amplified and sequenced. The experiment involved DNA samples extracted from bacterial isolates derived from all 24 experimental variants and isolated from inoculants as well as from a $R$. leguminosarum reference strain (DSM 30143). Amplification of the 16S rRNA region produced a single sharp band of the expected size (1,500 bp).

Sequencing of the product revealed, however, that despite careful sterilization of nodules and using a Rhizobium-selective medium sequences of other bacterial species were mostly detected. Sequences of seven samples (apart from $R$. leguminosarum bv. viceae DSM 30143) could only be analyzed, as the rest of sequencing patterns presumably resulted from multiple templates that were amplified. Among them only one sequence belonged to $R$. leguminosarum bv. viceae (Table 3 ). Such result may indicate that the pea nodules as well as the Nitragine ${ }^{m}$ inoculant were dominated by bacterial species other than $R$. leguminosarum.

To eliminate the Rhizobium-negative samples, the isolates were tested for the presence of nodC gene. This test also confirmed the theoretical ability of strains to form nodules with roots. This experiment was conducted on 46 bacterial strains isolated from the YEM agar plates. These were from one to four isolates per one experimental variant and one strain from each inoculant (IUNG and Nitragine) along with the reference strain of $R$. leguminosarum. The expected 930-bp region of 1,300-bp long nodC gene was observed only in the case of 22 of 46 samples ( 21 bacterial isolates from nodules and 1 from the IUNG inoculant; Table 4). The remaining isolates, including the reference strain and the bacteria isolated from a commercial Nitragine $^{\text {m }}$ inoculant, lacked the expected product. The comparison of the obtained nodC sequences with the NCBI showed that all samples resulted in positive identification of $R$. leguminosarum bv. viceae.

The RFLP analysis using five restriction enzymes (AluI, BamHI, BsuRI, EcoRI, and MspI) provided conclusive results only in the case of BamHI digestion; therefore, the results obtained only for this enzyme are shown (Figure 1). This reaction resulted in the digestion of a 930-bp long PCR product (nodC gene) into two or three fragments of various sizes, revealing two patterns (A and $\mathrm{B}$ ). In the pattern $\mathrm{A}$, the digestion process gave two fragments, 780 and $150 \mathrm{bp}$, whereas in the pattern $\mathrm{B}$, the digestion resulted in three fragments, 560, 220, and $150 \mathrm{bp}$. In some cases, the digestion revealed a mixed profile $(A+B)$, that is, four bands were observed 780, 560, 220, and $150 \mathrm{bp}$, indicating that in those cases two profiles were combined in the same sample.

\section{Discussion}

The first part of our experiment showed that the abundance of nodule-dwelling bacteria can be associated with the variety of the pea plants combined with the inoculant used. In our study, the combination of the noncommercial IUNG inoculant coupled with the "Klif" variety of pea was characterized by a significantly higher number of CFU per nodule of bacteria grown on Rhizobium-selective medium than the one observed for all other variants. Also Klimek-Kopyra et al. (2017) observed that the application of IUNG inoculant resulted in the formation of a higher

Table 3. Identification of bacteria colonizing pea nodules

Tabelle 3. Identifizierung der Bakterien, welche die Erbsenknöllchen besiedelten

\begin{tabular}{lll}
\hline Variant & Bacteria species & $\begin{array}{l}\text { Maximum identity (\%) } \\
\text { IUNG }\end{array}$ \\
\cline { 2 - 3 } Nitragine ${ }^{\mathrm{TM}}$ & Rhizobium leguminosarum bv. viciae USDA 2370 strain USDA 2370; ATCC 10004 & 99 \\
Klif (uninoculated) & Bacillus megaterium strain IAM 13418 & 99 \\
Tarchalska (uninoculated) & Stenotrophomonas maltophilia strain IAM 12423 & 99 \\
Tarchalska + IUNG & Stenotrophomonas maltophilia strain IAM 12423 & 99 \\
Klif + Nitragine ${ }^{\mathrm{TM}}$ & Stenotrophomonas maltophilia strain IAM 12423 & 99 \\
Tarchalska + Nitragine $^{\mathrm{TM}}$ & Stenotrophomonas maltophilia strain IAM 12423 & 98 \\
\hline
\end{tabular}




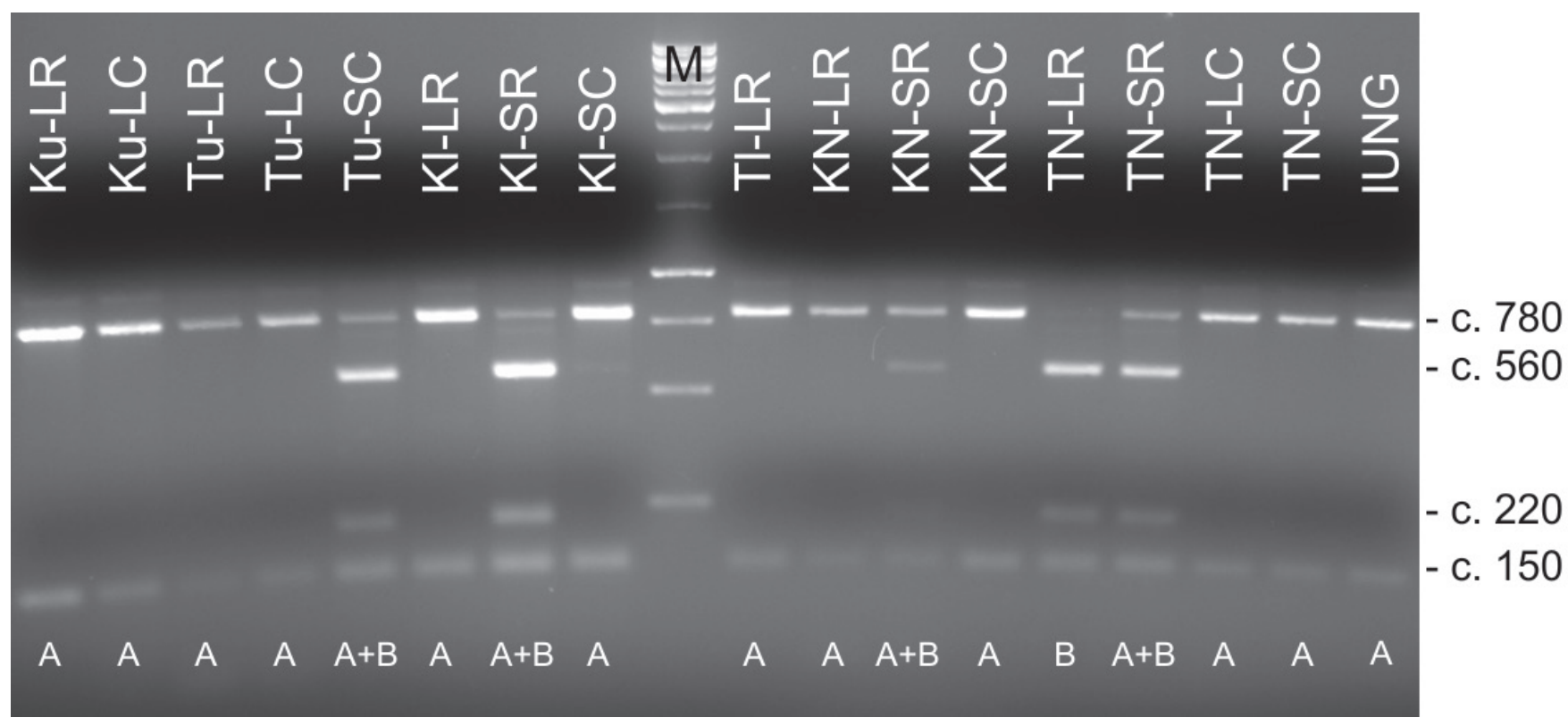

Figure 1. BamHI digestion of nodC gene of 17 selected Rhizobium leguminosarum samples. Letters at the top of the figure show experimental variants, whereas letters at the bottom of the figure show the digestion patterns.

Legend for the top of the figure: Ku, uninoculated "Klif” pea plants; KI, "Klif” plants inoculated with IUNG; KN, "Klif” plants inoculated with Nitragine $^{\mathrm{TM}}$; Tu, uninoculated "Tarchalska" pea plants; TI, "Tarchalska” plants inoculated with IUNG; TN, "Tarchalska” plants inoculated with Nitragine $^{\mathrm{TM}}$; IUNG, bacterial isolates derived from the IUNG inoculant; LR, LC, SR, and SC refer to the types of nodules: LR, large red; LC, large cream; SR, small red; SC, small cream.

Legend for the bottom of the figure: M, GeneRuler ${ }^{\mathrm{TM}} 1 \mathrm{~kb}$ DNA Ladder (Thermo Scientific); A, B, and C, clear digestion profiles; A + B, mixed digestion profiles.

Abbildung 1. BamHI-Verdauung des nodC-Gens von 17 ausgewählten Proben von Rhizobium leguminosarum. Buchstaben oben in der Abbildung zeigen experimentelle Varianten, während Buchstaben unten in der Abbildung die Verdauungsmuster zeigen.

number of seeds per pod, pods per plant, and seeds per plant. Even though the presence of small, cream-colored nodules is considered as evidence of ineffective nitrogen fixation (Carr et al., 2000), no significant differences were observed in this analysis in the number of bacteria isolated from nodules of various size and color. Similarly, the size and color of nodules did not have an impact on the detection of $R$. leguminosarum based on the nodC gene.

Sequencing of $16 \mathrm{~S}$ rRNA gene revealed the presence of bacterial species, other than $R$. leguminosarum, including Stenotrophomonas maltophilia, Bacillus megaterium, and Achromobacter insolitus. B. megaterium, as well as many other bacteria, was reported to be one of endophytic bacteria in pea cultivars (Elvira-Recuanco and van Vuurde, 2000; Sturz et al., 1997). Similarly, species of Stenotrophomonas spp. were detected as bacterial isolates derived from nodules of several leguminous plants (Dudeja et al., 2011). Sharikov and Khakimov (2010) using the 16S rRNA gene study revealed that the leguminous plant nodule-isolated bacteria were related to Rhizobium, Burkholderia, and Achromobacter genera.
The detection of nodC gene fragment revealed that not all nodule-derived strains possessed the expected nodC fragment. Because nodulation (nod) genes are essential for symbiosis and $n o d C$ is a key symbiotic gene that, together with $\operatorname{nod} A$ and $\operatorname{nodB}$, is responsible for the synthesis of the core structure of Nod factors (Bontemps et al., 2005), the lack of this particular gene in bacteria isolated from pea nodules as well as from isolates derived from the Nitragine ${ }^{\mathrm{TM}}$ could indicate that nodules of the six plants were dominated by bacteria that belonged to other nitrogen-fixing species. However, in order to certainly confirm whether the Rhizobium strains contained in Nitragine ${ }^{\mathrm{TM}}$ possess or lacks the nod $C$ gene, that is, whether they are capable of initiating the effective nodulation process, the PCR detection of this gene should be conducted on the DNA samples extracted not from individual isolates growing on agar media but from the representative sample of the inoculant itself.

For a number of samples, RFLP analysis revealed the presence of multiple $\operatorname{nod} C$ variants within a single isolate; this was indicated by the mixed digestion patterns in BamHI reaction. Such result indicates either the occurrence of mul- 
Table 4. Detection of nodC gene in the studied bacterial isolates

Tabelle 4. Nachweis des nodC-Gens in den untersuchten Bakterienisolaten

\begin{tabular}{|c|c|c|c|c|}
\hline Isolate No. & Variant & Nodule & Number of isolates per variant & nod $C$ presence \\
\hline 1 & Klif (uninoculated) & Large red & 1 & Yes \\
\hline 2 & Klif (uninoculated) & Large red & 2 & No \\
\hline 3 & Klif (uninoculated) & Small red & 1 & No \\
\hline 4 & Klif (uninoculated) & Small red & 2 & No \\
\hline 5 & Klif (uninoculated) & Large cream & 1 & Yes \\
\hline 6 & Klif (uninoculated) & Small cream & 1 & Yes \\
\hline 7 & Klif (uninoculated) & Small cream & 2 & No \\
\hline 8 & Tarchalska (uninoculated) & Large red & 1 & Yes \\
\hline 9 & Tarchalska (uninoculated) & Small red & 1 & Yes \\
\hline 10 & Tarchalska (uninoculated) & Small red & 2 & No \\
\hline 11 & Tarchalska (uninoculated) & Large cream & 1 & Yes \\
\hline 12 & Tarchalska (uninoculated) & Small cream & 2 & Yes \\
\hline 13 & Klif + IUNG & Large red & 1 & Yes \\
\hline 14 & Klif + IUNG & Small red & 1 & Yes \\
\hline 15 & Klif + IUNG & Large cream & 1 & Yes \\
\hline 16 & Klif + IUNG & Small cream & 1 & No \\
\hline 17 & Tarchalska + IUNG & Large red & 1 & Yes \\
\hline 18 & Tarchalska + IUNG & Large red & 2 & No \\
\hline 19 & Tarchalska + IUNG & Large red & 3 & No \\
\hline 20 & Tarchalska + IUNG & Large red & 4 & No \\
\hline 21 & Tarchalska + IUNG & Small red & 1 & No \\
\hline 22 & Tarchalska + IUNG & Small red & 2 & No \\
\hline 23 & Tarchalska + IUNG & Small red & 3 & No \\
\hline 24 & Tarchalska/IUNG & Large cream & 1 & No \\
\hline 25 & Tarchalska + IUNG & Large cream & 2 & No \\
\hline 26 & Tarchalska + IUNG & Large cream & 3 & No \\
\hline 27 & Tarchalska + IUNG & Small cream & 1 & No \\
\hline 28 & Klif + Nitragine ${ }^{\mathrm{TM}}$ & Large red & 1 & No \\
\hline 29 & Klif + Nitragine $^{\mathrm{TM}}$ & Large red & 2 & No \\
\hline 30 & Klif + Nitragine ${ }^{\mathrm{TM}}$ & Large red & 3 & No \\
\hline 31 & Klif + Nitragine ${ }^{\mathrm{TM}}$ & Large red & 4 & No \\
\hline 32 & Klif + Nitragine ${ }^{\mathrm{TM}}$ & Small red & 1 & Yes \\
\hline 33 & Klif + Nitragine ${ }^{\mathrm{rm}}$ & Small red & 2 & No \\
\hline 34 & Klif + Nitragine ${ }^{\mathrm{ru}}$ & Large cream & 1 & Yes \\
\hline 35 & Klif + Nitragine $^{\mathrm{TM}}$ & Small cream & 1 & Yes \\
\hline 36 & Tarchalska/Nitragine $^{\mathrm{TM}}$ & Large red & 1 & Yes \\
\hline 37 & Tarchalska + Nitragine ${ }^{\mathrm{TM}}$ & Large red & 2 & No \\
\hline 38 & Tarchalska + Nitragine $^{\mathrm{TM}}$ & Small red & 1 & Yes \\
\hline 39 & Tarchalska + Nitragine ${ }^{\mathrm{TM}}$ & Large cream & 1 & Yes \\
\hline 40 & Tarchalska + Nitragine $\mathrm{e}^{\mathrm{TM}}$ & Small cream & 1 & Yes \\
\hline 41 & Tarchalska + Nitragine ${ }^{\mathrm{TM}}$ & Small cream & 2 & Yes \\
\hline 42 & Tarchalska/Nitragine $^{\mathrm{TM}}$ & Small cream & 3 & Yes \\
\hline 43 & Tarchalska + Nitragine ${ }^{\mathrm{TM}}$ & Small cream & 4 & Yes \\
\hline 44 & Nitragine $\mathrm{e}^{\mathrm{rM}}$ & Nonapplicable & 1 & No \\
\hline 45 & IUNG & Nonapplicable & 1 & Yes \\
\hline 46 & R. leguminosarum bv. viceae DSM 30143 & Nonapplicable & 1 & No \\
\hline
\end{tabular}


tiple Rhizobium strains in a single nodule or the presence of rhizobial strains carrying multiple variants of nodC gene in a Sym plasmid. The restriction digestion of nodC gene indicated the presence of more than one rhizobial strain in one nodule, as RFLP analysis resulted in mixed digestion patterns (at least two different restriction patterns could be detected within a single sample). It is not unusual, as numerous studies confirm that nodules of leguminous plants may often harbor more than one Rhizobium spp. strain (Gross and Vidaver, 1978; Simms and Taylor, 2002).

\section{Conclusions}

The performed study showed that the abundance of nodule-dwelling bacteria is affected by a few factors, among which the variety of pea plants coupled with the type of inoculant seem to have the most significant impact. Most abundant nodule colonization was observed in the case of the "Klif" variety combined with a noncommercial inoculant. We also observed that the pea nodules may harbor a very diverse community of bacteria, and this diversity was also observed within the nodC-carrying strains of Rhizobium isolated from the pea nodules. Moreover, even though the $\operatorname{nod} C$ gene is required for establishing a symbiosis with plants, it was not detected in the majority of nodule-derived bacterial isolates. This could have been caused by the fact that the nod genes are located on a plasmid; therefore, after the completion of nodulation, this plasmid could have been lost because it constitutes a genetic burden for the bacteria. However, because of the fact that the nod genes are essential for establishing a legume-bacterium symbiosis, in order for an inoculant to be effective, it needs not only to carry viable Rhizobium strains but it also requires the presence of a Sym plasmid that, as we demonstrated, can be lost in many generations of bacteria. Thus, the lack of nodC gene in strains isolated from a commercial Nitragine inoculant proves that even if $R$. leguminosarum are abundant, they might not be efficient in nodulation. However, the results do not disqualify the examined inoculant, as we are not fully convinced that the bacterial strains that were able to grow on the YEM medium are in fact the representative group. In order to conduct a more certain assessment of the nodulation efficiency of an inoculant, the PCR tests aimed at detection of the nodC gene should be carried out on the DNA extracts derived from the inoculant itself.

\section{Acknowledgments}

The study was supported by the Ministry of Science and Higher Education in Poland (Project no. N N310 151837) and by the statutory measures of the University of Agriculture (DS KM/3158).

\section{References}

Amarger, N., Macheret, V. and G. Laguerre (1997): Rhizobium gallicum sp. nov. and Rhizobium giardinii sp. nov., from Phaseolus vulgaris nodules. International Journal of Systemic Bacteriology 47, 996-1006.

Bontemps, C., Golfier, G., Gris-Liebe, C., Carrere, S., Talini, L. and C. Boivin-Masson (2005): Microarray-based detection and typing of the Rhizobium nodulation gene nodC: Potential of DNA arrays to diagnose biological functions of interest. Applied and Environmental Microbiology 71, 8042-8048.

Carr, P.M., Henson, R.A. and K.R. McKay (2000): Inoculation and fertilization of field pea. 2000 Annual Report, Agronomy Section, Dickinson Research Extension Center, Dickinson, ND. https://www.ag.ndsu.edu/archive/dickinso/research/1999/agron99e.htm. Accessed on 16 December 2018.

Christou, P. (1997): Biotechnology applied to grain legumes. Field Crops Research 53, 83-97.

Debellé, F., Rosenberg, C., Vasse, J., Maillet, F., Martinéz, E., Dénarié, J. and G. Truchet (1986): Assignment of symbiotic developmental phenotypes to common and specific nodulation (nod) genetic loci of Rhizobium meliloti. Journal of Bacteriology 168, 1075-1086.

Doré, T., Meynard, J.M. and M. Sebillotte (1998): The role of grain number, nitrogen nutrition and stem number in limiting pea crop (Pisum sativum) yields under agricultural conditions. European Journal of Agronomy 8, 29-37.

Dudeja, S.S., Giri, R., Saini, R., Suneja-Madan, P. and E. Kothe (2011): Interaction of endophytic microbes with legumes. Journal of Basic Microbiology 51, 1-13.

Elvira-Recuenco, M. and J.W. van Vuurde (2000): Natural incidence of endophytic bacteria in pea cultivars. Canadian Journal of Microbiology 46, 1036-1041.

FAO (2013): World Food and Agriculture. Statistical Yearbook. Food and Agriculture Organization of the United States, Rome.

Gloudemans, T., Bhuvaneswari, T.V., Moerman, M., van Brussel, T., van Kammen, A. and T. Bisseling (1989): 
Involvement of Rhizobium leguminosarum nodulation genes in gene expression in pea root hairs. Plant Molecular Biology 12, 157-167.

Gross, D.C. and A.K. Vidaver (1978): Bacteriocin-like substances produced by Rhizobium japonicum and othe slow-growing rhizobia. Applied and Environmental Microbiology 36, 936-943.

Klimek-Kopyra, A., Strojny, J., Zając, T., Ślizowska, A., Klimešova, J. and R.W. Neugschwandtner (2017): Ordinal regression model for pea seed mass. Die Bodenkultur 68: Journal of Land Management, Food and Environment, 81-87.

Laguerre, G., Nour, S.M., Macheret, V., Sanjuan, J., Drouin, P. and N. Amarger (2001): Classification of rhizobia based on nodC and nifH geneanalysis revealsa close phylogenetic relationship among Phaseolus vulgaris symbionts. Microbiology 147, 981-993.

Patel, J.B. (2001): 16S rRNA gene sequencing for bacterial pathogen identification in the clinical laboratory. Molecular Diagnostics 6, 313-321.

Selvakumar, G., Panneerselvam, P. and A. Ganeshamurthy (2013): Legume root nodule associated bacteria. In: Plant Microbe Symbiosis: Fundamentals and Advances. Springer, New Delhi, India, pp. 215-232.

Shakirov, Z.S. and S.A. Khakimov (2010): Symbiosis of nodule bacteria with perennial xerophyte leguminous plants of Central Asia. Agricultural Sciences 1, 24-38.

Simms, E.L. and D.L. Taylor (2002): Partner choice in nitrogen fixation mutualisms of legumes and rhizobia. Integrative and Comparative Biology 42, 369-380.
Stephens, J.G.H. and H.M. Rask (2000): Inoculant production and formulation. Field Crops Research 65, 249-258.

Sturz, A.V., Christies, B.R., Matheson, B.G. and J. Nowak (1997): Biodiversity of endophytic bactera which colonize red clover nodules, roots, stems and foliage and their influence on host growth. Biology and Fertility of Soils 25, 13-19.

Tas, E., Saano, A., Leinonen, P. and K. Lindström (1995): Identification of Rhizobium spp. in peat-based inoculants by DNA hybridizayion and PCR and its application in inoculant quality control. Applied and Environmental Microbiology 61, 1822-1827.

Thies, J.E., Singleton, P.W. and B.B. Bohlool (1991): Influence of the size of indigenous rhizobial populations on establishment and symbiotic performance of introduced rhizobia on field-grown legumes. Applied and Environmental Microbiology 57, 19-28.

Vincent, J.M. (1970): A manual for the practical study of root-nodules bacteria. IBP Handbook, Blackwell, Oxford, UK.

Wadhwa, K., Dudeja, S.S. and R.K. Yadav (2011): Molecular diversity of native rhizobia trapped by five field pea genotypes in Indian soils. Journal of Basic Microbiology 51, 89-97.

Weisburg, W.G., Barns, S.M., Pelletier, D.A. and D.J. Lane (1991): $16 \mathrm{~S}$ ribosomal DNA amplification for phylogenetic study. Journal of Bacteriology 173, 697-703. 